\title{
Carbonate precipitation in brine - a potential trigger for tropospheric ozone depletion events
}

\author{
R. Sander ${ }^{1}$, J. Burrows ${ }^{2}$, and L. Kaleschke ${ }^{2, *}$ \\ ${ }^{1}$ Air Chemistry Department, Max-Planck Institute of Chemistry, P.O. Box 3060, 55020 Mainz, Germany \\ ${ }^{2}$ Institute of Environmental Physics and Remote Sensing, University of Bremen, Germany \\ *now at: Institute of Oceanography, Center for Marine and Atmospheric Research, University of Hamburg, Germany
}

Received: 3 July 2006 - Published in Atmos. Chem. Phys. Discuss.: 25 July 2006

Revised: 22 September 2006 - Accepted: 16 October 2006 - Published: 17 October 2006

\begin{abstract}
Tropospheric ozone depletion events (ODEs) at high latitudes were discovered 20 years ago and are attributed to bromine explosions. However, an unresolved issue is the explanation of how the acid-catalyzed reaction cycle is triggered in atmospheric particles derived from alkaline sea water. By simulating the chemistry occuring in polar regions over recently formed sea ice, we can model successfully the transformation of inert sea-salt bromide to reactive bromine monoxide $(\mathrm{BrO})$ and the subsequent ODE when precipitation of calcium carbonate from freezing sea water is taken into account. In addition, we found the temperature dependence of the equilibrium $\mathrm{BrCl}+\mathrm{Br}^{-} \rightleftharpoons \mathrm{Br}_{2} \mathrm{Cl}^{-}$to be important.
\end{abstract}

\section{Introduction}

Several times every spring measured surface ozone concentrations in polar regions drop below the detection limit (Wennberg, 1999). Barrie et al. (1988) were the first to notice that this disappearence is connected to increased concentrations of bromine. Satellite measurements found that clouds of $\mathrm{BrO}$ are widespread in spring throughout the Arctic and also the Antarctic (Richter et al., 1998; Wagner et al., 2001). Since the production of hydroxyl radicals at high latitudes is relatively small, this natural source of reactive halogens represents an additional and important regional contribution to the oxidative capacity of the atmosphere. The reaction of bromide $\left(\mathrm{Br}^{-}\right)$with hypobromous acid $(\mathrm{HOBr})$ in aerosols was proposed by Fan and Jacob (1992) to explain how the necessary bromine concentrations could be sustained by recycling through the aqueous phase. However, since the direct reaction is not fast enough, the following reaction sequence takes place (Vogt et al., 1996):

$$
\mathrm{HOBr}+\mathrm{H}^{+}+\mathrm{Cl}^{-} \rightarrow \mathrm{BrCl}+\mathrm{H}_{2} \mathrm{O}
$$

Correspondence to: R. Sander

(sander@mpch-mainz.mpg.de)

$$
\begin{aligned}
\mathrm{BrCl}+\mathrm{Br}^{-} & \rightleftharpoons \mathrm{Br}_{2} \mathrm{Cl}^{-} \\
\mathrm{Br}_{2} \mathrm{Cl}^{-} & \rightleftharpoons \mathrm{Br}_{2}+\mathrm{Cl}^{-} \\
\hline \Sigma: \quad \mathrm{HOBr}+\mathrm{H}^{+}+\mathrm{Br}^{-} & \rightarrow \mathrm{Br}_{2}+\mathrm{H}_{2} \mathrm{O}
\end{aligned}
$$

The bromine, released as $\mathrm{Br}_{2}$ or $\mathrm{BrCl}$, is photolyzed to produce $\mathrm{Br}$ atoms, which catalytically destroy $\mathrm{O}_{3}$. Since $\mathrm{Re}-$ action (R1) is acid-catalyzed, it has been a scientific puzzle how it can proceed in particles derived from alkaline sea water. Previous model studies of the bromine explosion did not explain or address how adequate acidity is achieved. Either they did not consider aqueous-phase chemistry at all (Tang and McConnell, 1996; Zeng et al., 2003; Lehrer et al., 2004), assumed emissions of already activated bromine (Borken, 1996; Sander et al., 1997), or artificially acidified the model aerosol (Fan and Jacob, 1992; Michalowski et al., 2000; Evans et al., 2003). Although bromine could also be produced on the frozen surface of sea ice (Adams et al., 2002), this source would quickly be exhausted since diffusion through solid ice is slow. A consistent mechanism is required to explain the observations. Here, we present a box model study showing that precipitation of calcium carbonate from freezing sea water triggers the transformation of inert sea-salt bromide to reactive bromine.

\section{Model description}

To investigate the role of carbonate precipitation, we have implemented it into the atmospheric chemistry model MECCA (Sander et al., 2005), describing the release of halogens from sea salt aerosol under conditions of the polar boundary layer at $82^{\circ} \mathrm{N}$. MECCA contains both bromine and chlorine chemistry in the gas phase and aerosols, with fully $\mathrm{pH}$-dependent aqueous-phase chemistry. The model runs start on 31 March with initial mixing ratios as shown in Table 1. To account for NO from the snow surface (Beine et al.,

Published by Copernicus GmbH on behalf of the European Geosciences Union. 
Table 1. Initial gas-phase mixing ratios and aqueous-phase concentrations.

\begin{tabular}{llrrc}
\hline phase & species & Arctic & Antarctic & unit \\
\hline \multirow{4}{*}{ gas } & $\mathrm{O}_{3}$ & 40 & 30 & $\mathrm{nmol} / \mathrm{mol}$ \\
& $\mathrm{NO}$ & 10 & 2 & $\mathrm{pmol} / \mathrm{mol}$ \\
& $\mathrm{NO}_{2}$ & 10 & 2 & $\mathrm{pmol} / \mathrm{mol}$ \\
& $\mathrm{SO}_{2}$ & 100 & 30 & $\mathrm{pmol} / \mathrm{mol}$ \\
& $\mathrm{C}_{2} \mathrm{H}_{6}$ & 2000 & 300 & $\mathrm{pmol} / \mathrm{mol}$ \\
& $\mathrm{C}_{2} \mathrm{H}_{4}$ & 26 & 10 & $\mathrm{pmol} / \mathrm{mol}$ \\
& $\mathrm{C}_{2} \mathrm{H}_{2}$ & 329 & 10 & $\mathrm{pmol} / \mathrm{mol}$ \\
\hline \multirow{4}{*}{ aerosol } & $\mathrm{Cl}^{-}$ & 4.978 & & $\mathrm{~mol} / \mathrm{L}$ \\
& $\mathrm{Br}^{-}$ & 0.007500 & $\mathrm{~mol} / \mathrm{L}$ \\
& $\mathrm{HCO}_{3}^{-}$ & 0.01470 & $\mathrm{~mol} / \mathrm{L}$ \\
\hline
\end{tabular}

2002), a constant (24 h) flux of $10^{8} \mathrm{~cm}^{-2} \mathrm{~s}^{-1}$ is emitted. After a spin up of a few days, sea-salt particles of $2 \mu \mathrm{m}$ radius are injected into the air on 4 April. The initial liquid water content (LWC) of the model aerosol is $5 \times 10^{-10} \mathrm{~m}^{3} / \mathrm{m}^{3}$, and it decays exponentially with a lifetime of 3 days. The particles consist of well-mixed, liquid, concentrated brine $(c=5 \mathrm{~mol} / \mathrm{L})$. Their chemical composition is that of sea water minus the precipitated carbonate, as shown in Table 1.

\section{Carbonate precipitation and aerosol generation}

Sea water is the primary source of the halogens (McConnell et al., 1992). Recently, Kaleschke et al. (2004) showed that regions experiencing "potential frost flower" (PFF) conditions were the sources of the $\mathrm{BrO}$ clouds. Such regions are characterized by the opening of the ice at very low temperature, which results in new ice formation and can lead to the growth of frost flowers. Here, we propose a mechanism by which airborne sea-salt particles can be formed under PFF conditions. In the spring, leads open up, e.g. caused by ice flows that drift away. The relatively warm sea water is exposed to the cold air. Evaporation humidifies the air above the lead (Fig. 1a). The top layer of the sea water cools down and starts to freeze. This produces a water ice layer. Sea-salt components with a low solubility also precipitate into this ice layer. The remaining liquid is expelled from the ice lattice and forms a brine layer on top of the freshly formed ice. This brine is a concentrated sea-salt solution depleted in lowsolubility components (Fig. 1b). Frost flowers can grow on the ice, or snow flakes (generated in the previously humidified air) fall onto the ice. The surface of the frost flowers or snow flakes becomes coated with the brine through capillary forces. Finally, a wind gust transforms them into airborne particles. If the surface is neither covered by frost flowers nor snow flakes, the wind gust may still produce aerosol particles directly from the brine layer (Fig. 1c). This aerosol generation process is supported by observations (Wagenbach

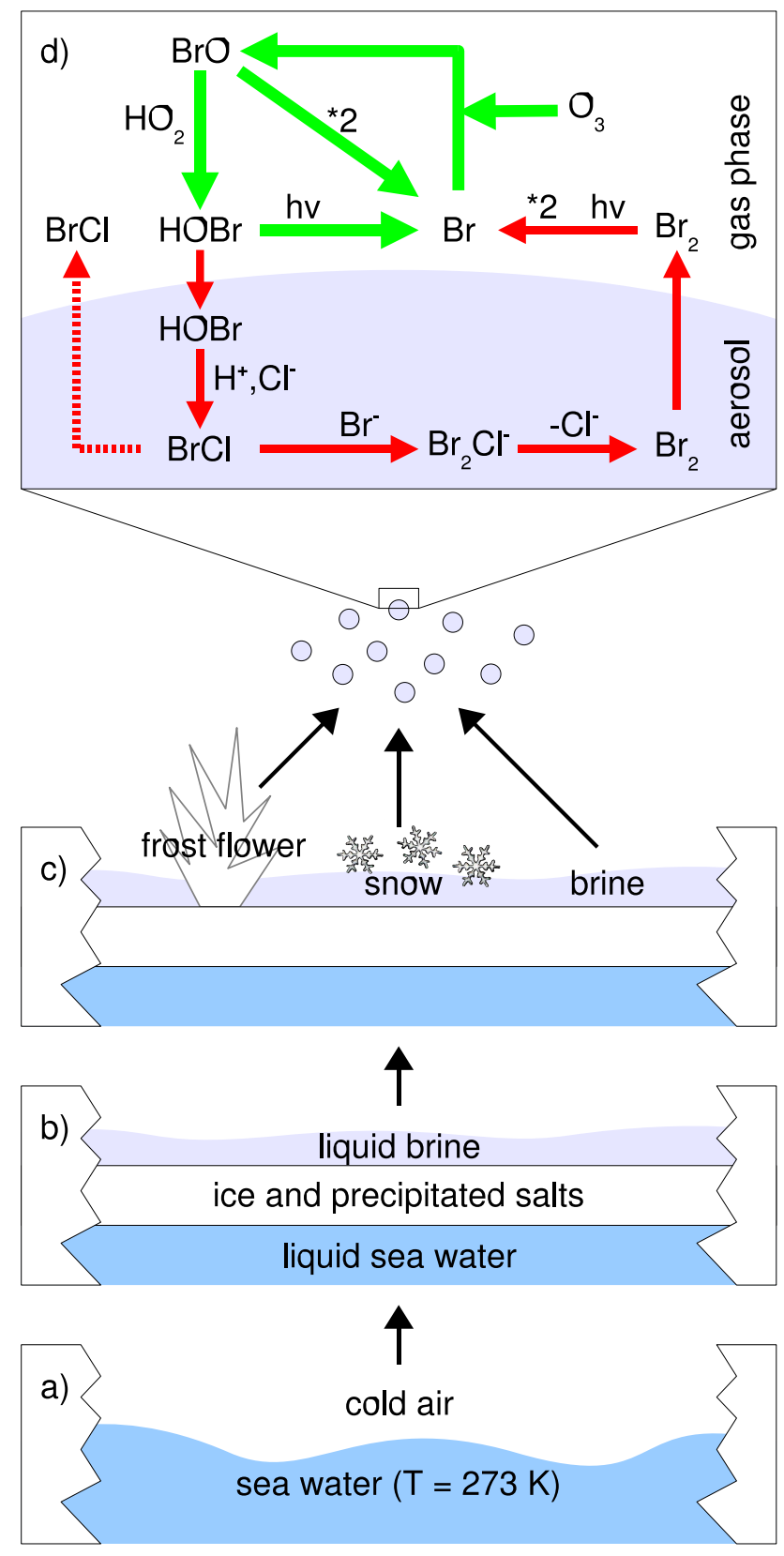

Fig. 1. Schematic of our proposed aerosol generation scheme (see text for details). The upper panel shows how the multiphase chemistry in the gas phase and in the aerosol starts the bromine explosion (red arrows) and ozone depletion (green arrows).

et al., 1998; Rankin et al., 2002; Rankin and Wolff, 2003; Wolff et al., 2003, 2006) of sulfate fractionation, showing that mirabilite $\left(\mathrm{Na}_{2} \mathrm{SO}_{4}\right)$ precipitation must have occurred on the ground before the particles were injected into the atmosphere.

An important component of sea salt with a low solubility is $\mathrm{CaCO}_{3}$. Laboratory experiments by Papadimitriou et al. (2003) have shown carbonate precipitation during sea 


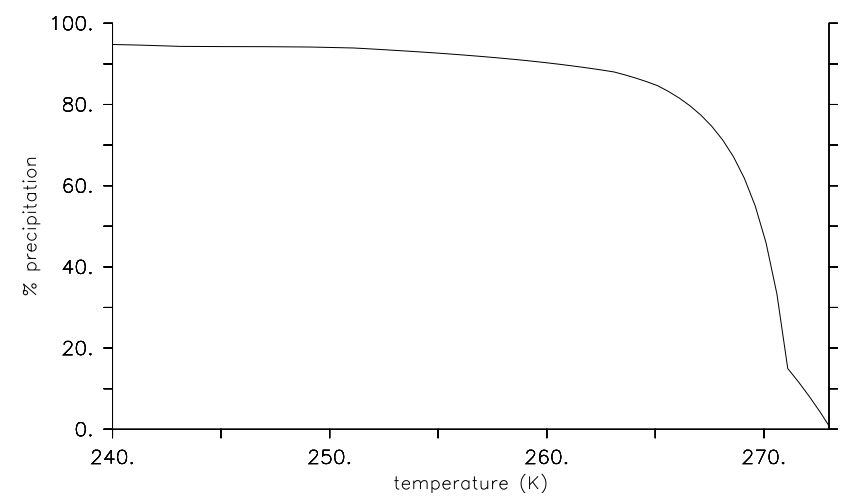

Fig. 2. Precipitation of calcium carbonate during the freezing of sea water. The curve was calculated prescribing salinity data for the remaining brine (Richardson, 1976) and assuming an equilibrium with atmospheric $\mathrm{CO}_{2}$. As the acidity and Henry's law coefficients of $\mathrm{CO}_{2}$ are not available for subzero temperatures and concentrated brines, we used values at $0{ }^{\circ} \mathrm{C}$ and a salinity of $35 \%$. We expect that the increased solubility of $\mathrm{CO}_{2}$ at subzero temperatures and the salting out effect at increased salinity cancel out at least partially.

ice formation. Measurements of Antarctic aerosol samples by Wagenbach et al. (1998) are also consistent with precipitation of $\mathrm{CaCO}_{3}$, even though $\mathrm{Ca}$ fractionation was not seen. Precipitation of $\mathrm{CaCO}_{3}$ affects carbonate but has only a very small effect on $\mathrm{Ca}$ which has a much higher concentration in sea water than carbonate. Literature data about the exact degree of $\mathrm{CaCO}_{3}$ precipitation is sparse. Assuming equilibrium with atmospheric $\mathrm{CO}_{2}$, we find that below $265 \mathrm{~K}$ most of the carbonate precipitates (see Fig. 2 and also the electronic supplement at http://www.atmos-chem-phys. net/6/4653/2006/acp-6-4653-2006-supplement.pdf). The removal of $\mathrm{CaCO}_{3}$ reduces the buffering capacity of the sea water and thus facilitates its acidification.

\section{Results and discussion}

\subsection{Arctic conditions}

To identify the key processes responsible for the release of bromine, different MECCA simulations have been undertaken, as summarized in Table 2. In the PRECIP run (black lines in Fig. 3), we assume 30\% carbonate precipitation relative to sea water. We use this conservative estimate since we cannot be sure that the thermodynamic equilibrium with large precipitation is reached. Ozone drops from $40 \mathrm{nmol} / \mathrm{mol}$ to almost zero within about 2 days, and $\mathrm{BrO}$ is between 30 and $40 \mathrm{pmol} / \mathrm{mol}$. The aerosol is initially alkaline but reaches acidities as low as $\mathrm{pH} 3$ during the model run. This acidity results from the oxidation of $\mathrm{SO}_{2}$ and $\mathrm{NO}_{2}$, and it is the main driving force behind the bromide activation. The model shows bromide depletion while the bromine explosion is active $(\mathrm{EF}(\mathrm{Br})<1$ in Fig. 3e), and accumulation
Table 2. List of Arctic model simulations.

\begin{tabular}{|c|c|}
\hline Name & Description \\
\hline PRECIP & $30 \%$ carbonate precipitation \\
\hline NOPRECIP & $0 \%$ carbonate precipitation \\
\hline ROOMTEMP & $\begin{array}{l}\text { Equilibrium constant } K_{\mathrm{R} 2} \text { at } 298 \mathrm{~K}, 0 \% \\
\text { carbonate precipitation }\end{array}$ \\
\hline LOWSALT & $\begin{array}{l}\text { Sea-salt aerosol } 20 \% \text { less than in PRECIP } \\
\text { run }\end{array}$ \\
\hline
\end{tabular}

of $\mathrm{HBr}$ in the remaining aerosol $(\mathrm{EF}(\mathrm{Br})>1)$ once all ozone has been destroyed. These results successfully reproduce features observed during the ozone depletion events. Snow samples (which represent the chemical composition of airborne particles) were found to be depleted in bromide up to $50 \mathrm{~km}$ downwind of the open ocean. Further away from the sea water source $(50-100 \mathrm{~km})$, bromide enrichment relative to sea-water sodium was found (Simpson et al., 2005).

To show the effect of the carbonate precipitation, we compared the PRECIP run to a sensitivity study NOPRECIP, in which $\mathrm{CaCO}_{3}$ does not precipitate. In the PRECIP case the carbonate precipitation results in a very significant decrease in $\mathrm{pH}$, stimulating the acid-catalyzed production of $\mathrm{Br}_{2}$. The NOPRECIP case clearly shows very different results (red lines in Fig. 3). Here, the available acids are not sufficient to remove the carbonate buffer, and the aerosol $\mathrm{pH}$ does not fall below 6 . The ozone destruction is much slower, and about half of the ozone still remains after 3 days.

The critical reaction, i.e. the rate-limiting step, of the bromine activation is equilibrium (R2). As its temperature dependence has not yet been reported in the literature, we have estimated its equilibrium constant $K_{\mathrm{R} 2}$ as a function of temperature $T$ by combining available thermodynamic data from Liu and Margerum (2001):

$$
\begin{aligned}
K_{\mathrm{R} 2} & =\frac{K_{\mathrm{R} 4}}{K_{\mathrm{R} 3} \times K_{\mathrm{R} 1}}=\frac{\left[\mathrm{Br}_{2} \mathrm{Cl}^{-}\right]}{\left[\mathrm{Br}^{-}\right][\mathrm{BrCl}]} \\
& =1.8 \times 10^{4} \frac{\mathrm{dm}^{3}}{\mathrm{~mol}} \times \exp \left(7500 \mathrm{~K}\left(\frac{1}{T}-\frac{1}{298.15 \mathrm{~K}}\right)\right)
\end{aligned}
$$

At low temperature, equilibrium (R2) shifts to the right, and $\mathrm{BrCl}$ is transformed into $\mathrm{Br}_{2}$, propagating the bromine activation cycle. At high temperature, however, the dissociation of $\mathrm{Br}_{2} \mathrm{Cl}^{-}$towards $\mathrm{BrCl}$ and $\mathrm{Br}^{-}$is fast and slows the cycle. Based on NOPRECIP, we performed the sensitivity study ROOMTEMP, using the value at $298.15 \mathrm{~K}$ for $K_{\mathrm{R} 2}$ instead of the value extrapolated to $240 \mathrm{~K}$, as in the other runs. Remarkably, there is now little or no ozone destruction (blue lines in Fig. 3).

Another unresolved issue concerns the temporal evolution of bromine and chlorine. To investigate it, we performed further sensitivity studies. In the PRECIP run, there is suffi- 

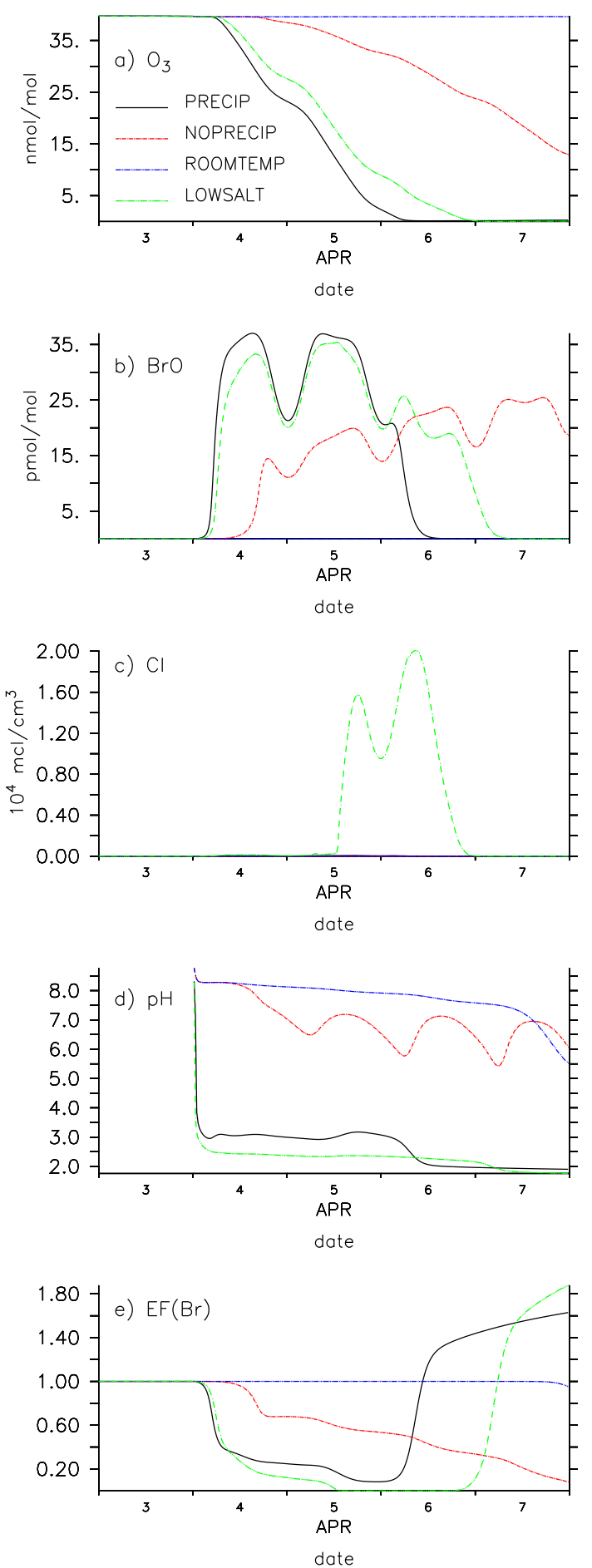

Fig. 3. Results of the Arctic MECCA box model runs. Shown are (a) ozone, (b) $\mathrm{BrO}$, (c) $\mathrm{Cl}$, (d) aerosol pH, and (e) the bromide enrichment factor $\mathrm{EF}(\mathrm{Br})$. Sea water has by definition a value of $\mathrm{EF}(\mathrm{Br})=1$. Values of $\mathrm{EF}(\mathrm{Br})>1$ represent enrichment of bromine in the aerosol, whereas values of $\mathrm{EF}(\mathrm{Br})<1$ indicate depletion of bromine. Further sensitivity runs (not shown in the figure) showed that varying the aerosol lifetime between 2 and 4 days had no significant effect on the ozone loss rate.
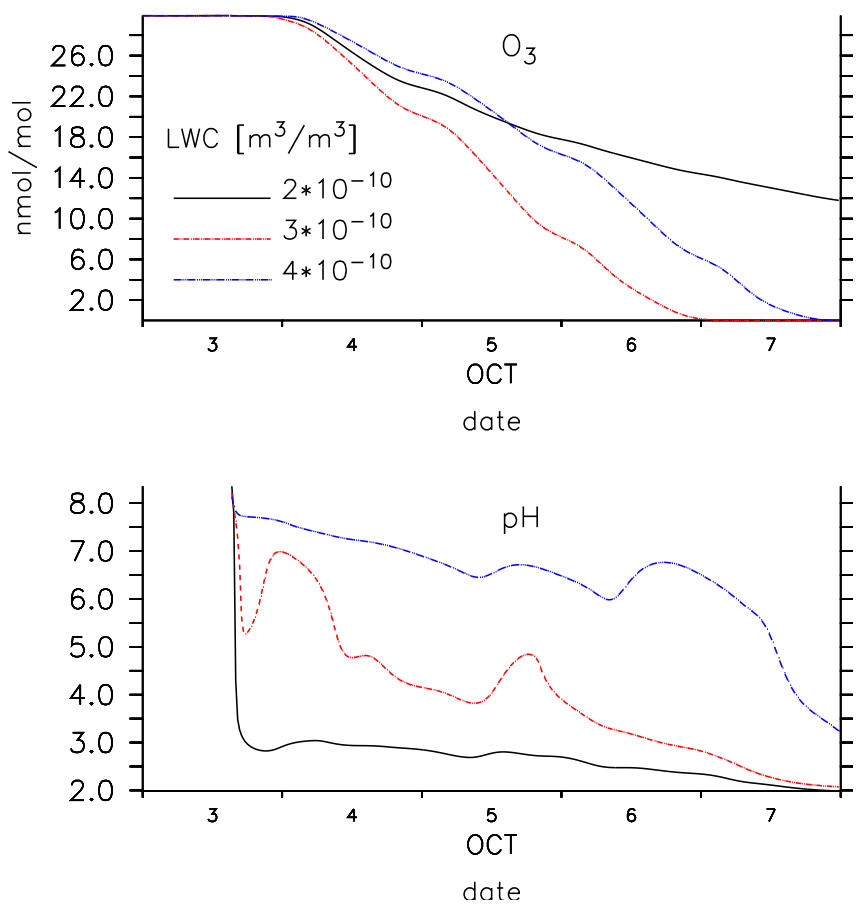

Fig. 4. Ozone and aerosol $\mathrm{pH}$ in the Antarctic model runs. The model is initialized with the mixing ratios shown in the right column of Table 1. The liquid water content (LWC) of the sea-salt aerosol is varied between 2 and $4 \times 10^{-10} \mathrm{~m}^{3} / \mathrm{m}^{3}$. A carbonate precipitation of $60 \%$ was used for the Antarctic model runs. Further sensitivity runs (not shown in the figure) showed that under the Antarctic conditions chosen for these model runs, less carbonate precipitation did not achieve significant ozone depletion.

cient aerosol so that there is always some bromide left in the aerosol $(\mathrm{EF}(\mathrm{Br})>0$, see black line in Fig. 3e) throughout the ODE. BrCl produced in Reaction (R1) does not leave the particle but reacts further with $\mathrm{Br}^{-}$towards $\mathrm{Br}_{2}$ via Reactions (R2) and (R3). Therefore, chlorine activation is small. In the sensitivity study LOWSALT (green lines in Fig. 3), the amount of aerosol is reduced by $20 \%$. Here, all the aerosol bromide is used up before the ozone depletion has been completed. The aqueous-phase chemistry switches to a different regime. $\mathrm{BrCl}$ cannot react with $\mathrm{Br}^{-}$anymore and instead escapes to the gas phase, where it is quickly photolyzed into $\mathrm{Br}$ and $\mathrm{Cl}$. Consistent with measurements by Foster et al. (2001), most of the chlorine atoms originate from the photolysis of $\mathrm{BrCl}$, not $\mathrm{Cl}_{2}$. The integrated $\mathrm{Cl}$ atom concentration in the LOWSALT scenario compares well with Arctic measurements by Jobson et al. (1994).

\subsection{Antarctic conditions}

The Arctic and the Antarctic are very different with respect to the amount of acidity available. In the Arctic, the outflow of pollution from the populated and industrialized parts of the northern hemisphere results in the precursors of in- 
organic acidity and acidic aerosol reaching even remote regions. Thus, there is potentially sufficient $\mathrm{SO}_{2}$ to acidify the aerosol as a result of the accumulation of atmospheric acids during the Arctic winter from sources in Eurasia and North America. In spite of this, our model results suggest that even at $100 \mathrm{pmol} / \mathrm{mol} \mathrm{SO}$, carbonate precipitation is necessary to acidify the sea-salt aerosol. The Antarctic has the cleanest surface layer air on our planet. Although some acidity is generated from the oxidation of oceanic dimethyl sulfide (DMS) and naturally produced nitrogen oxides, the total amount is small. Nevertheless, bromine explosions are observed in the Southern hemisphere above sea ice, too (Wagner et al., 2001). To investigate Antarctic conditions, further simulations have been undertaken, as shown in Fig. 4. We vary the amount of sea-salt aerosol that is injected into the air. There is a delicate balance between available sea salt, which provides bromide but is alkaline, and available acidity. The fastest ozone destruction rate is obtained with the medium aerosol concentration. With less aerosol, the amount of bromide is smaller and the ozone destruction rate is accordingly less. With more aerosol, the available acids are no longer sufficient to neutralize the sea-water alkalinity. The $\mathrm{pH}$ remains high, and the ozone destruction rate is low. Thus, ozone destruction rates increase with increasing amount of sea salt, as long as the acidity is sufficient to neutralize the remaining buffer capacity after carbonate precipitation. Additional acids lower the $\mathrm{pH}$ further but do not accelerate the ozone destruction.

\section{Conclusions}

Our model calculations demonstrate that a previously neglected process, namely the precipitation of carbonate, might play a key role in the triggering of the acid-catalyzed bromine explosion, and thus in the depletion of tropospheric ozone. Provided the brine on the surface of the ice and that wicked onto the frost flowers reaches a sufficiently low temperature, the mechanism described above could also take place directly on the sea ice surface. Our results are consistent with observations and can explain why bromine release is accelerated under low temperature conditions experienced at high latitudes. Halogen activation is limited by both salt content and available acidity. During the ozone depletion event, bromine is activated first. Chlorine activation only starts when the particles have lost all their bromide. Most of the chlorine originates from the photolysis of $\mathrm{BrCl}$. Production of chlorine atoms from $\mathrm{Cl}_{2}$ is small.

Accurate kinetic and thermodynamic data at low temperature and high salinity are required to confirm the estimates made in this study. Experimental data are needed for the solubility product of $\mathrm{CaCO}_{3}$ and the equilibrium coefficient of the key reaction $\mathrm{BrCl}+\mathrm{Br}^{-} \rightleftharpoons \mathrm{Br}_{2} \mathrm{Cl}^{-}$under conditions typical for the polar boundary layer.
In addition, 3-dimensional modeling studies are required to understand the spatial structure of ODEs and $\mathrm{BrO}$ clouds. The impact of climate change on this important source of oxidative capacity at high latitude requires further careful investigation. Decreasing or increasing PFF conditions could lead to less or more bromine explosions, respectively. Field studies of the interaction of cold air masses coming from the PFF regions with the surface brine are needed to quantify how much these can contribute to the observed enhanced $\mathrm{BrO}$ and ODE phenomena. Finally, we recommend that the physical mechanism by which aerosol is generated over freshly formed sea ice is studied both in the laboratory and the field. This is required to assess accurately the oxidative capacity at high latitudes, including the release of halogen, and their global significance for tropospheric chemistry.

Acknowledgements. For very helpful discussions, we would like to thank R. A. Cox, R. von Glasow, M. Lawrence, P. Shepson, W. R. Simpson, R. Weller, and E. W. Wolff. This work has in part been funded through the Max-Planck Society, the University of Bremen, the European Union (ACCENT), the DLR and the German Research Council (DFG).

Edited by: R. von Glasow

\section{References}

Adams, J. W., Holmes, N. S., and Crowley, J. N.: Uptake and reaction of $\mathrm{HOBr}$ on frozen and dry $\mathrm{NaCl} / \mathrm{NaBr}$ surfaces between 253 and 233 K, Atmos. Chem. Phys., 2, 79-91, 2002, http://www.atmos-chem-phys.net/2/79/2002/.

Barrie, L. A., Bottenheim, J. W., Schnell, R. C., Crutzen, P. J., and Rasmussen, R. A.: Ozone destruction and photochemical reactions at polar sunrise in the lower Arctic atmosphere, Nature, 334, 138-141, 1988.

Beine, H. J., Honrath, R. E., Dominé, F., Simpson, W. R., and Fuentes, J. D.: $\mathrm{NO}_{\mathrm{x}}$ during background and ozone depletion periods at Alert: Fluxes above the snow surface, J. Geophys. Res., 107D, 4584, doi:10.1029/2002JD002082, 2002.

Borken, J.: Ozonabbau durch Halogene in der arktischen Grenzschicht: Reaktionskinetische Modellrechnungen zu einem Frühjahrsphänomen, Diplomarbeit, Ruprecht-Karls-Universität Heidelberg, Germany, 1996.

Evans, M. J., Jacob, D. J., Atlas, E., Cantrell, C. A., Eisele, F., Flocke, F., Fried, A., Mauldin, R. L., Ridley, B. A., Wert, B., Talbot, R., Blake, D., Heikes, B., Snow, J., Walega, J., Weinheimer, A. J., and Dibb, J.: Coupled evolution of $\mathrm{BrO}_{\mathrm{X}}-\mathrm{ClO}_{\mathrm{X}}{ }^{-}$ $\mathrm{HO}_{\mathrm{x}}-\mathrm{NO}_{\mathrm{x}}$ chemistry during bromine-catalyzed ozone depletion events in the Arctic boundary layer, J. Geophys. Res., 108D, 8368, doi:10.1029/2002JD002732, 2003.

Fan, S.-M. and Jacob, D. J.: Surface ozone depletion in Arctic spring sustained by bromine reactions on aerosols, Nature, 359, 522-524, 1992.

Foster, K. L., Plastridge, R. A., Bottenheim, J. W., Shepson, P. B., Finlayson-Pitts, B. J., and Spicer, C. W.: The role of $\mathrm{Br}_{2}$ and $\mathrm{BrCl}$ in surface ozone destruction at polar sunrise, Science, 291, 471-474, 2001. 
Jobson, B. T., Niki, H., Yokouchi, Y., Bottenheim, J., Hopper, F., and Leaitch, R.: Measurements of $\mathrm{C}_{2}-\mathrm{C}_{6}$ hydrocarbons during the polar sunrise 92 experiment: Evidence for $\mathrm{Cl}$-atom and $\mathrm{Br}-$ atom chemistry, J. Geophys. Res., 99D, 25 355-25 368, 1994.

Kaleschke, L., Richter, A., Burrows, J., Afe, O., Heygster, G., Notholt, J., Rankin, A. M., Roscoe, H. K., Hollwedel, J., Wagner, T., and Jacobi, H.-W.: Frost flowers on sea ice as a source of sea salt and their influence on tropospheric halogen chemistry, Geophys. Res. Lett., 31, L16114, doi:10.1029/2004GL020655, 2004.

Lehrer, E., Hönninger, G., and Platt, U.: A one dimensional model study of the mechanism of halogen liberation and vertical transport in the polar troposphere, Atmos. Chem. Phys., 4, 24272440, 2004,

http://www.atmos-chem-phys.net/4/2427/2004/.

Liu, Q. and Margerum, D. W.: Equilibrium and kinetics of bromine chloride hydrolysis, Environ. Sci. Technol., 35, 1127-1133, 2001.

McConnell, J. C., Henderson, G. S., Barrie, L., Bottenheim, J., Niki, H., Langford, C. H., and Templeton, E. M. J.: Photochemical bromine production implicated in Arctic boundary-layer ozone depletion, Nature, 355, 150-152, 1992.

Michalowski, B. A., Francisco, J. S., Li, S.-M., Barrie, L. A., Bottenheim, J. W., and Shepson, P. B.: A computer model study of multiphase chemistry in the Arctic boundary layer during polar sunrise, J. Geophys. Res., 105D, 15 131-15 145, 2000.

Papadimitriou, S., Kennedy, H., Kattner, G., Dieckmann, G. S., and Thomas, D. N.: Experimental evidence for carbonate precipitation and $\mathrm{CO}_{2}$ degassing during sea ice formation, Geochim. Cosmochim. Acta, 68, 1749-1761, 2003.

Rankin, A. M. and Wolff, E. W.: A year-long record of sizesegregated aerosol composition at Halley, Antarctica, J. Geophys. Res., 108D, 4775, doi:10.1029/2003JD003993, 2003.

Rankin, A. M., Wolff, E. W., and Martin, S.: Frost flowers: Implications for tropospheric chemistry and ice core interpretation, J. Geophys. Res., 107, 4683, doi:10.1029/2002JD002492, 2002.

Richardson, C.: Phase relationship in sea ice as a function of temperature, J. Glaciol., 17, 507-519, 1976.

Richter, A., Wittrock, F., Eisinger, M., and Burrows, J. P.: GOME observations of tropospheric $\mathrm{BrO}$ in northern hemispheric spring and summer 1997, Geophys. Res. Lett., 25, 2683-2686, 1998.

Sander, R., Vogt, R., Harris, G. W., and Crutzen, P. J.: Modeling the chemistry of ozone, halogen compounds, and hydrocarbons in the Arctic troposphere during spring, Tellus, 49B, 522-532, 1997.
Sander, R., Kerkweg, A., Jöckel, P., and Lelieveld, J.: Technical Note: The new comprehensive atmospheric chemistry module MECCA, Atmos. Chem. Phys., 5, 445-450, 2005, http://www.atmos-chem-phys.net/5/445/2005/.

Simpson, W. R., Alvarez-Aviles, L., Douglas, T. A., Sturm, M., and Domine, F.: Halogens in the coastal snow pack near Barrow, Alaska: Evidence for active bromine air-snow chemistry during springtime, Geophys. Res. Lett., 32, L04811, doi:10.1029/2004GL021748, 2005.

Tang, T. and McConnell, J. C.: Autocatalytic release of bromine from Arctic snow pack during polar sunrise, Geophys. Res. Lett., 23, 2633-2636, 1996.

Vogt, R., Crutzen, P. J., and Sander, R.: A mechanism for halogen release from sea-salt aerosol in the remote marine boundary layer, Nature, 383, 327-330, doi:10.1038/383327A0, 1996.

Wagenbach, D., Ducroz, F., Mulvaney, R., Keck, L., Minikin, A., Legrand, M., Hall, J. S., and Wolff, E. W.: Sea-salt aerosol in coastal Antarctic regions, J. Geophys. Res., 103D, 1096110974, 1998.

Wagner, T., Leue, C., Wenig, M., Pfeilsticker, K., and Platt, U.: Spatial and temporal distribution of enhanced boundary layer $\mathrm{BrO}$ concentrations measured by the GOME instrument aboard ERS2, J. Geophys. Res., 106D, 24 225-24 235, 2001.

Wennberg, P.: Bromine explosion, Nature, 397, 299-301, 1999.

Wolff, E. W., Rankin, A. M., and Röthlisberger, R.: An ice core indicator of Antarctic sea ice production?, Geophys. Res. Lett., 30, 2158, doi:10.1029/2003GL018454, 2003.

Wolff, E. W., Fischer, H., Fundel, F., Ruth, U., Twarloh, B., Littot, G. C., Mulvaney, R., Röthlisberger, R., de Angelis, M., Boutron, C. F., Hansson, M., Jonsell, U., Hutterli, M. A., Lambert, F., Kaufmann, P., Stauffer, B., Stocker, T. F., Steffensen, J. P., Bigler, M., Siggaard-Andersen, M. L., Udisti, R., Becagli, S., Castellano, E., Severi, M., Wagenbach, D., Barbante, C., Gabrielli, P., and Gaspari, V.: Southern Ocean sea-ice extent, productivity and iron flux over the past eight glacial cycles, Nature, 440, 491-496, 2006.

Zeng, T., Wang, Y., Chance, K., Browell, E. V., Ridley, B. A., and Atlas, E. L.: Widespread persistent near-surface ozone depletion at northern high latitudes in spring, Geophys. Res. Lett., 30, 2298, doi:10.1029/2003GL018587, 2003. 